\title{
The Formation and Development Trends of the Consulting Market in Russia
}

Ilshat T. Sabirov

Kazan (Volga region) Federal University, 420008, Kazan, Russia

Liudmila A. Ponkratova

Amur State University, 675027, Blagoveschensk, Russia

Nadezhda A. Gracheva

Southwestern State University, 305040, Kursk, Russia

Sergey V. Kiselev

Kazan National Research Technological University, 420015, Kazan, Russia

Nataliya A. Zaitzeva

Immanuel Kant Baltic Federal University, 236041, Kaliningrad, Russia

Larisa E. Fatikhova

Kazan (Volga region) Federal University, 420008, Kazan, Russia

Alexey D. Chudnovskiy

Moscow State University of Management, 109542, Moscow, Russia

\section{Doi:10.5901/mjss.2015.v6n2s3p188}

\section{Abstract}

In the conditions of rapid growth of service industries and, above all, business services, the importance of advisory services (consulting) is steadily enhancing for the domestic economy and the growth of its competitiveness. The article analyzes the basic processes occurring in the modern Russian market of consulting services, the trends and patterns of its development, including the growing processes of concentration and centralization, the underdevelopment of market institutions, the lack of legislation regulating this market segment, structural defects associated with the excessive income growth of the management consulting. All this allowed us to draw some important conclusions about the unstable and contradictory nature of the development of the domestic market of consulting, the deformation of its structure and the absence of the state policy in the sphere of regulation of the consulting services market, and to develop recommendations for its stabilization, including the improvement of legislation in the field of intellectual property, the expansion and strengthening of the foreign economic positions of the consulting companies in Russia, the efficiency improvement of their participation in the international division of labor. The article is intended for students studying methods of conducting marketing research on the market of consulting services, teachers of the discipline "Marketing in services", "Consulting" as well as for marketing managers and managers of consulting companies elaborating strategies for their development.

Keywords: consulting services, development trends, concentration, centralization, structural shifts in the market of consulting services, the types of consulting services.

\section{Introduction}

\subsection{The relevance of the problem}

The rapid development of service industries and the enhancement of their role in the formation of GDP is the hallmark of 
the transformational stage of the development of the domestic economy, and the level of development of the services sector is the basic characteristic of the development of a society. The increasing importance of various service industries is associated not only with the dominance of this sector in the structure of the national economy, but also an active interrelation and interpenetration of different service industries among themselves, when the process of convergence leads to new, hitherto not known services (Zvoronov, 2002). Therefore, in this sector the key factors of the economic growth are formed, including intangible assets, and information technology. The degree of development of the services becomes one of the main criteria for assessing the competitiveness of the economies of various countries (Voskolovich, 2007).

In the process of development of market institutions of the economy, the share of services in business is constantly increasing, which include, above all, consulting, the value and volume of which increase significantly as far as the specialization of the business extends, when the involvement of consulting firms begins to significantly affect the growth of company revenues (Tslaph, 2011).

The thriving consulting is able to actively influence the most important areas of small companies' economic growth (Bavina, 2008), including the changes in the structure of their production due to a growing sector of consulting activity in terms of the complexity of the combinatorial satisfaction of their needs in complex highly-professional services related to financial, managerial, and tax problem solutions (Kirina, 2006), sales, and marketing nature (Zilberman, 2006). Additionally, the consulting promotes active growth of the influence of managerial, organizational and economic innovations on the formations of the companies' competitive development strategy, when consulting becomes a tool for strengthening their competitiveness, the sustainable development of the national economy as a whole (Gerasimov, 2008). relevant.

On this basis, the trends in the formation and development of the consulting market in Russia seem to be quite

\section{Methodological Framework}

\subsection{The research objectives}

The objectives of the research were to identify the trends and regularities of the formation and development of the domestic market of consulting, analysis of the dynamics of its development, assessment of its contribution to the national economy's GDP, the rationale for the classification of the domestic consulting market subjects, identification of the sectoral preferences of the leading segments of the domestic consulting market, analysis of the main structural changes and trends in the market of consulting services related mainly to the intensification of the processes of concentration and centralization.

\subsection{The theoretical and methodological framework}

The theoretical and methodological basis of the research was the fundamental provisions of the economic theory, the theory of the services, scientific works of the domestic and foreign scientists on the research of the trends and regularities of the formation and development of the consulting market in the globalization context, the Federal and regional normative legal acts, the official statistical data and the primary data from the economic entities' reporting published in the official press.

The methodological basis of the conducted research was the integrated use of a wide variety of situational, dynamic, comparative, structural and functional, economic and statistical analysis methods.

\section{The Results}

3.1 The dynamic parameters of the formation and development of the domestic consulting market have been investigated in the crisis conditions using the evaluation index of gross domestic product coverage by the consulting services

The domestic market of consulting services is one of the most dynamic and, at the same time, unstable growing segments of the services sector market. 
Table 1. The dynamics of the key figures of the gross domestic product and the scope of consulting services ratio for the period from 2004 to 2011

\begin{tabular}{|c|c|c|c|c|c|c|c|c|}
\hline & 2004 & 2005 & 2006 & 2007 & 2008 & 2009 & 2010 & 2011 \\
\hline Gross domestic product, billion rubles & 17027.2 & 21609.8 & 26917.2 & 33247.5 & 41276.8 & 38807.2 & 45172.7 & 54585.6 \\
\hline $\begin{array}{l}\text { The index of the GDP physical volume in percentage } \\
\text { against the previous year }\end{array}$ & 107.2 & 106.4 & 108.2 & 108.5 & 105.2 & 92.2 & 104.3 & 104.3 \\
\hline $\begin{array}{l}\text { The amount of the consulting and information services, } \\
\text { billion rubles }\end{array}$ & 38.7 & 54.3 & 69.8 & 96.6 & 123.4 & 76.9 & 88.8 & 103.9 \\
\hline $\begin{array}{l}\text { The index of the physical volume of the consulting } \\
\text { services, \% to the previous year }\end{array}$ & 136.2 & 140.3 & 128.5 & 138.4 & 127.7 & 62.3 & 115.5 & 117.0 \\
\hline The amount of the consulting services to GDP, in percent & 0.23 & 0.25 & 0.26 & 0.29 & 0.30 & 0.19 & 0.19 & 0.19 \\
\hline The index of the GDP coverage by the consulting services & 0.22 & 0.25 & 0.26 & 0.29 & 0.30 & 0.19 & 0.19 & 0.19 \\
\hline
\end{tabular}

The Source: calculated by the author according to the official data of Rosstat and the "Expert RA" Agency.

According to the data given by us as a result of the calculations based on the official data of Rosstat (Federal state statistics service, 2012) and the Agency "Expert RA" (Ranking, 2012), the development of the consultancy market is characterized by a relatively high dynamics (see tab. 1). Thus, the index of the physical volume of the consulting services, in percentage to the previous year, is significantly ahead throughout the entire period from 2004 to 2011 volume index of GDP. If the latter during the entire period did not exceed $108.2 \%$ (2007), the similar indicator for the market of consulting services at its maximum value had been $140.3 \%$ in 2005. In other words, the growth rate of the market volumes of consulting services was 5 times more than the similar GDP growth rate for the period from 2004 to 2011 (Ranking, 2012).

Particularly actively in the pre-crisis period up to 2008 the share of consulting services in GDP was growing, the maximum value of which in 2008 was $0.3 \%$, which is $30 \%$ higher than the level achieved in 2011 . All this suggests that the market for advisory services still has not reached its pre-crisis positions in the importance of the country's GDP.

In addition, the dynamics of the indicators of the volumes and the growth rates of the consulting services market and GDP are characterized by the comparability of their parameters and a specific pattern, which indicates the current relationship and the increasing participation of the consulting services in the development of the country's economy as a whole.

So, to evaluate the role of the consulting market in GDP the index of the GDP coverage by consulting services (Velikanov, 2011) is recommended to be used, which is calculated as:

$$
V_{G D P}=\frac{V c}{G D P-V c} \times 100 \%
$$

where:

$V_{G D P}$ - the index of the GDP growth rate coverage by the consulting services;

$V_{c}$ - the amount of the consulting services.

The performed calculations with the specified index allowed determining that the level of GDP maintenance by the advisory services especially was growing in the pre-crisis period and reached $0.3 \%$ in 2008 . However, in the post-crisis period, this rate decreased to $0.19 \%$.

The use of the indicator of the level of coverage by GDP consulting services allows a more comprehensive assessment of the role and the importance of this segment of the services market in the economic development, as well as its importance for the formation and development of the necessary infrastructure conditions conducive to achieving and maintaining competitive advantages in various sectors of the domestic economy.

Therefore, the trends in the growth of the consulting services amount arouse the progressively increased attention to the development of this sector of the economy, because of its low intensity, while at the same time with a high level of profitability and intellectual labor. That is why this market is increasingly involving the scientific potential in its sphere and is becoming attractive for investment (Deeva, 2010).

3.2 The preconditions for accelerated development of the domestic consulting market are justified in the modern conditions, including its intellectual and investment attractiveness, as well as the growing demand for energy-saving technologies and industrial safety.

It should be noted that the further analysis of the trends in the formation and development of the consulting market we expect to carry out on the basis of the available official statistics data on 150 leading consulting companies. The 
representativeness of this group is quite high, as the total revenues and the income of this group exceed $60 \%$ of the total volume of the Russian market of consulting services that allows distributing this information on assessment of the processes happening in general in the country's consulting market.

Thus, in 2011 the total revenue of 150 largest consulting groups in Russia increased by $21 \%$ and reached almost 104 billion rubles. All this suggests that the prospects for development of the national market of consulting services are quite positive, and the market conditions are conducive to its development and strengthening.

Most experts associate the positive dynamics of the consulting services market development with the overcoming of the crisis phenomena in the economy in general and the increase of the investment in most sectors of the domestic economy, which boosted demand for advisory services in minimizing the investment risks (Buleev, 2010). In other words, the increase in demand for consulting services is associated with a loss of development opportunities in the period of crisis, and the accumulated pent-up demand during the crisis period got an opportunity to be fully implemented.

The confirmation of this conclusion is testified by the data on the growth of the total revenue of 150 largest consulting companies in 2011. Thus, according to the official rating of the "Expert RA" Agency the highest rates of the revenue growth in 2011 were shown by the advisory companies specializing in the consultations on the organization of production (68\%), the aggregate amount of which exceeded 2.5 billion rubles. This type of consulting services is significantly ahead of all the others in the pace of their growth, which suggests about the possibilities to boost the real sector of the domestic economy (Ranking, 2011).

According to experts, the active growth in this segment of the consulting services market is also due to the growing demand for energy-saving technologies and industrial safety, which is considered by many companies as the main points of the economic growth and the compliance with international standards. That is why a growing demand among industrial companies is observed in the field of energy audit and examination of production for compliance with international standards of energy efficiency. These activities are considered as important components of improving their competitiveness.

In addition, an important component of large corporations' competitiveness is the development and preparation of feasibility studies for investment, analysis and expertise of design and estimate documentation, construction and technical audit. Among the major corporate clients of the production consulting, the enterprises of the oil and gas industry can be selected, of the metallurgical industry, electric-power industry and mechanical engineering, which accounted for almost $70 \%$ of the total revenues of the largest consulting companies.

\subsection{A specific structure of the domestic consulting market has been classified and its most actively developing segments have been identified.}

Quite high demand is traditionally pent up for the consulting services of companies specializing in services for personnel management, the revenue growth rates of which in 2011 exceeded 140\%, and the total proceeds amounted to 2.8 billion rubles. In the structure of this type of consulting services stand out comprehensive programs of leadership development, as well as evaluation of staff, including automated methods, management case study-tests and tests of professional competencies. Thus there is a reduction in traditional types of consulting services in the field of personnel management, including the creation of management competencies and procedures of management according to the objectives, as well as the development of bonus systems.

The group of dynamically developing types of consulting services is comprised of consulting firms specializing in services for IT-developments and systems integration (23\%), tax consulting (21\%), strategic consulting (20.5\%), consulting in assessment activities (19\%), IT-management consulting (18\%), legal consulting (13\%) and financial consulting (9\%) (Nikiforov, 2011).

Most clearly among these types of consulting the consulting in assessment activities and financial advisory services can be highlighted, a relatively high economic growth of which in the last five years has been due to the favorable economic conditions in general. For example, the total revenue of 150 largest consulting companies from the assessment reached 8.5 billion rubles by the end of 2011, and from the financial consulting -7.97 billion rubles, that is, on the comparable data, the increase for the year at $19 \%$ and $9 \%$ respectively. In addition, the important factors in the growth of these types of consulting services have been an active cost control, internal control systems and risk management, and also business planning and assessment of investment risks.

Moreover, with regard to the assessment activities, an integrated approach becomes more characteristic, which explains the relatively high income in this segment of services. In addition to the goals of deposits, banks, as a rule, are the sponsors for assessing and monitoring a mortgaged property, including not only inventory but also checking of a lot of parameters up to the quality and efficiency of the collateral. Often, in addition to simple evaluation, the projects include all 
the elements of "due diligence" until the technology audit.

Positive dynamics of the development was found in the area of tax and legal consulting; the total revenue for 150 of the largest consulting companies in Russia amounted to 7.49 and to 5.03 billion rubles, respectively. Faster grow the revenues from tax consulting - $21 \%$ for a year compared to $12 \%$ growth from legal consulting. Activation of these types of consulting services is associated by the experts with the growth of investment attractiveness of such types of businesses as transactions with land and real estate, construction, requiring special attention to the legal review issues, conducting legal proceedings in the areas of taxation, customs, anti-trust and currency regulation, copyright, labor and migration legislation, as well as legal protection of information (Kiselev, Sabirov, 2012).

The demand for legal services and tax consulting today is to a large extent associated with asset transactions, when foreign firms assess their prospects and the exit strategies for entering the Russian market, and the domestic business identifies the growth opportunities due to a synergetic effect (Kirina, 2006). In addition, there is an increasingly active market for mergers and acquisitions in the telecommunications, financial services, and the consumer goods.

The reduction in the total revenue in 2011 was recorded among the consulting companies specializing in services for marketing and public relations (- 29\%). However, in general, on this segment of consulting services the total revenue amounted to a relatively small amount, equal to 411 million rubles for the twenty companies, that looks relatively well in the overall ranking of the largest consulting companies (Ranking, 2012). Therefore, a noticeable change in the revenues of one significant player changes the overall picture, as well. On the other hand, the marketing, as the definition of new business development options and the substantiation of investment projects, is often a part of complex projects of strategic consulting and is not separately allocated by consulting companies. The most popular in the field of marketing consulting is to develop marketing and investment development programs with a step-by-step implementation mechanism for obtaining tangible financial and economic results. While the ready and expensive business-strategies developed in the outsourcing regime are becoming less popular (Kurbatova, 2005).

\subsection{The sectoral preferences of the largest consulting companies have been identified in the leading segments of the domestic consulting market}

The most informative is the sectoral pattern of the total volumes growth of consulting services provided by consulting companies in key sectors of the domestic economy. So, most of the consulting services demand growth accounts for the construction materials industry, the value of which in 2011 increased by 58\%. Thus, the increased demand for consulting services by the enterprises in the building materials industry is explained by the need to develop new business models, adequate to the growth of the investment activity in this sector, and also, as a result, by the increased demand for the construction materials. In addition, new development projects are appearing, the solvency of the population is increasing; the import substitution in the low and medium price segments of building materials is strengthening. These factors are forcing the domestic producers to actively engage the consulting firms to improve their competitiveness.

A significant increase in demand for consulting services accounted in 2011 for mechanical engineering (47\%), financial sector (36\%), construction and development (33\%), agriculture (29\%), transport sector (26\%) and trade (25\%).

Relatively "modest" growth rates in demand for consulting services - were less than $20 \%$ for 2011 - fall on such sectors as light industry (19\%), oil and gas (18\%), metallurgic industry (18\%), electric-power (13\%), pharmaceutical industry $(12 \%)$, food industry (7\%), telecommunication (6\%), housing and utilities (4\%), health care (3\%), chemical industry (3\%), public administration (2\%), education (1\%).

Such sectoral distribution of the growth rates in the demand for consulting services can be explained by several causes of a financial nature that is associated with the traditional lack of funds in such sectors as housing and utilities, health care and education. However, the low demand for consulting services in the domestic chemical industry is due to the fact that the majority of the industry enterprises are developing according to the model of "borrowing" of foreign advanced technology, "delivery" of which, as a rule, is accompanied by a full range of management services, training specialists and the necessary IT - support (Logvinenko, 2009).

\subsection{The analysis of the major structural changes has been carried out and the development tendencies of the Russian market of consulting services have been identified.}

Quite eloquent conclusions about the current processes of the formation and the development trends of the Russian market of consulting services can be made on the results of the analysis of 150 largest consulting companies' incomes. The analysis of the main structural changes and trends in the market of consulting services shows that more than half of all the income of this group of companies is only for two types of consultancy services - they are the IT-developments 
and system integration and the IT- management consulting (Kiselev, Sabirov, 2012). consulting.

The second half of the aggregate incomes of this group of the consulting firms - accounts for the other types of

Relatively high incomes in the field of IT-consulting reflect the traditional trend of development of this kind of consulting services. So, in 2011, the total revenue of the largest consulting companies specializing in software development and IT-management consulting was 53.3 billion rubles, of which $63 \%$ accounts for the developers' services and the system integrators, and $37 \%$ - for management consulting services.

Traditionally, high consumer demand is for such specific services of IT-consulting as the implementation of information systems for developing the efficiency and producibility of the business, integration and maintenance of management systems on the basis of $1 \mathrm{C}$, IBM, Microsoft, Oracle, SAP; process management of BPM ("business process management suites"), increasing the efficiency of enterprises of any size. The main trend of development of this sector of advisory services is that, according to the experts, a lot of requests over the past year have shifted from the IT-audits, concepts, strategies and optimization of IT management, to the development of systems projects, IT architectures and mobile technologies (Kiselev, Kurbiev, 2010).

The analysis of the sectoral structure of the revenues of the 150 largest consulting companies in the context of the basic sectors of the domestic economy at 2011 year-end (fig. 2) allows us to conclude that almost $40 \%$ of the total income of this group of consulting companies accounts for the oil and gas industry and the financial sector of the economy.

These two leaders of the consulting profitability are followed by such industries, in order of decreasing, as electricpower (15\%), public administration (9\%), telecommunications (8\%), transport (6.5\%), mechanical engineering (6\%), construction and development (5.5\%), trade (5.1\%), metallurgical complex (4.9\%), food industry (2\%), education (1.7\%) and utilities (1.6\%) (Ranking, 2012).

However, it should be noted that the development of the market of consulting services is contradictory. So, despite the significant growth in the revenues, and the revenue increase is observed in almost all the areas of consulting and industries in which they provided services, the market development is inert in nature, and, according to the experts, can lead to stagnation in the worst case.

Moreover, the majority of such consulting services as evaluation, financial management, legal and tax consulting are focused on the growing investment processes, which will lead to increased competition (Pesotskaya, 2006). These same trends are projected for the segment of IT consulting, which accounts for almost half of the volume of the consulting services market which is associated with modernization or modification of the implemented projects, or their support.

\subsection{The effects of the structural shifts have been justified in the domestic market of consulting, which are expressed mainly in activation of the concentration processes}

The analysis of the patterns and trends in the structural shifts in the market of consulting services allows us to note that its functioning was accompanied by quantitative and qualitative changes. Thus, the rapid growth of the size of the market had stabilized by 2005 , and in the subsequent period was characterized by a fairly high turnover and renewal of the participants. This was caused on the one hand by the lack of licensing requirements for this type of activity and the relatively low barriers to entry; on the other hand, the relatively low initial transaction costs of the business organization (Gromova, 2008).

Moreover, it can be argued that in the institutional structure of the consulting services market there have been significant changes associated with the growing trends of concentration and deepening of the consulting companies' specialization. This is evidenced by the data shown in tab. 2 .

Table 2. The dynamics of the processes of concentration in the market of consulting services in Russia for the period from 2005 to 2011

\begin{tabular}{|l|c|c|c|c|}
\hline \multirow{2}{*}{ In Russia } & The scope of advisory services, in billion rubles & \multirow{2}{*}{$\begin{array}{c}\text { The growth rates, in } \\
\text { percent }\end{array}$} \\
\cline { 2 - 4 } & 2005 & 2007 & 2011 & 117.9 \\
\hline 150 leading consulting companies & 54.3 & 96.6 & 145.6 & 147.8 \\
\hline $\begin{array}{l}\text { The proportion of the 150 leading consulting } \\
\text { companies in total in Russia }\end{array}$ & 37.1 & 70.3 & 103.9 & - \\
\hline
\end{tabular}


These statistics and the calculated figures on their basis testify to the ongoing processes of concentration in the market of consulting services in Russia. So, over $70 \%$ of the total volume of services in this segment of the market is less than $10 \%$ of the total number of the companies operating in it. Moreover, the growth rates of the provided consulting services to the group of 150 largest companies are almost 3 times higher than the similar rates for all the consulting companies in the country.

The research works of specialists and experts in the consulting market (Deeva, 2010, Kiselev and Sabirov, 2012) suggest that one of the major trends of its development was the transfer of the market since 2000 from the phase with a distinct oligopolistic nature and the dominance of foreign firms to the phase of its competitive development with the consistent growth in the participation of domestic companies in it and the achievement in 2010 of almost a parity condition.

In this case, the trend of the consulting business consolidation through varied forms of its mergers and the creation of consortia is observed, the dominant strategy of which is diversification. So, according to the "Expert RA" Agency, in 2007-2008 there were significant mergers in the consulting market of Russia, including the association of the leading consulting groups "IBS" and "Borlas", the companies "TopS Business Integrator" and "Systematics", "Optima" and "Alpha - Integrator" companies, as well as "REDLAB" and "CompuLink".

It should be noted that the processes of concentration on the consulting market of the country are acquiring a specific form of its monopolization, which is expressed in the formation and development of a relatively new form, which is represented by holding associations, created on the principles of co-operation. The content of this principle is well known; however, in the consulting market it has acquired a form of the cooperative consulting structure as an association for a specified period of intellectual and tangible assets of several companies in the development of complex consulting projects.

\section{Discussions}

The works of the researchers Bavina P. (2008), Voskolovich N. (2007), Gerasimova V. (2008), Deeva E. (2010), Zilberman M. (2006), Kiseleva S. and Sabirova I. (2012), Nikiforov N. (2011) and others are dedicated to the analysis of the trends in the formation and development of the Russian market of consulting services.

The works of Velikanov N. (2011), Buleev A. (2009), Gromova T. (2008), Zvoronov A. (2002), Kirina L. (2006), Kurbatova O. (2004), Logvinenko M. (2009), Pesotskaya B. (2006), Tslaph V. (2011) and others are dedicated to the analysis of structural developments in the modern Russian market of consulting.

However, a number of issues relating to the classification and structuring of the formation trends and the development trajectories of the domestic consulting market remain poorly studied, as evidenced by the unstable and contradictory dynamics of the consulting market in the country.

\section{Conclusion}

Thus, the analysis of the formation and development trends of the domestic market of consulting services allows us to make the following conclusions:

- the main trend of the formation and development of the market of consulting services is associated with a positive dynamics, accompanied by unsustainable development, caused by poor market institutions and, above all, the lack of legislation governing this type of economic activity, as well as mechanisms of state regulation of advisory business;

- the basis for the development of the consulting services market in recent years has been the active growth of investment activity in key sectors of the economy, primarily in the oil and gas, building materials industry, construction and agriculture;

- the analysis of the main structural changes and trends in the market of consulting services shows that more than half of its revenues accounts for IT-developments and systems integration and IT-management consulting, reflecting the general trends of computerization penetration in the key areas of the economic life;

- an important trend is associated with the focus of the largest consulting companies on preserving the accumulated skills and maintaining their competitiveness, including through the growth of its employees' professionalism;

- the need to improve the professional level of their employees has forced the leadership of the largest consulting companies to conduct a reduction in the number of the employees over the last three years at 7 percent, or nearly 25 thousand people; 
- - the absence of the state policy in the sphere of regulation of the consulting services market has led to an underestimation of the evolutionary approach to the formation of a civilized market by the largest companies' management;

- the low level and the lack of theoretical and methodological research works in the field of consulting services, which would significantly increase the level and quality of assessing this type of entrepreneurship, as well as its effectiveness;

- in-depth scientific and methodological research of consultancy will help to improve the concept of the consulting services development, including a comprehensive set of goals, objectives, principles of the whole system of consulting services, and aimed at shaping the public policy for regulating this type of economic activity.

- On the basis of the analysis of the current consulting activities the following directions of its development can be provided:

- development of intellectual property institutions and, as a consequence, of legislation in the sphere of intellectual activity, as an important part of the activation of processes to form a civilized market of consulting services;

- development of competition as the most important market institution that can influence the formation of the civilized competitive environment in the field of the consulting activities, stimulating business activity and attracting capital to the consulting market;

- consolidation and expansion of the global competitive advantages of the consulting companies in Russia in providing the consultancy services in the structural sectors of the domestic economy, such as energy, petroleum, petrochemical, gas, transportation, agriculture;

- extension and strengthening of the foreign economic positions of the consulting firms in Russia, improving the efficiency of their participation in the international division of labor.

\section{References}

Bavina P.A. (2008). Management consulting: a developing management model. SPb: Beresta.

Buleev A.I. (2009). The activity of small enterprises in the market of consulting and marketing services. Moscow: Architecture.

Deeva E.M. (2010). Theory and methodology of the consulting services marketing. Moscow: ITC Marketing.

Gerasimov V. (2008). Socio-economic efficiency of the management consulting services. Rostov-on-don.

Gromova, T.A. (2008) Consulting services and IT-outsourcing: the experience of use and the prospects of development. SPb.: SUEF.

Kirina L.S. (2006). The formation and development of the market services in tax consulting in Russia: the experience, problems, and prospects. Moscow: Economics.

Kiselev S.V., Kurbiev I.U. (2010) Features of forming the competitive strategies of the information and communication services development in the market, Bulletin of the Kazan Technological University, 2 (167-174).

Kiselev S.V., Sabirov I.F. (2012). Analysis of the main trends in the formation and development of the consulting services market in Russia, Bulletin of the Kazan Technological University, 21 (187-192).

Kurbatova O.V. (2005). The development of the consulting services market in Russia. Moscow: Unity.

Logvinenko, M.V. (2009). The current condition of the consulting services market, a Corporate consultant, 12 (67-72).

Nikiforov N.A. (2011). The basic preconditions for forming the system of the public electronic services in the Republic of Tatarstan, Bulletin of the Kazan Technological University, 5 (214-223).

Pesotskaya E.V. (2006). The services market of the management consulting: structural diagnostics. Russia's economic revival, 3 (2129).

Russian statistical yearbook 2011. M: Rosstat. 2012.

The ranking of the largest consulting companies (consulting groups) http://raexpert.ru/ratings/consulting//

Tslaph V.M. (2011). The development of the consulting business in the Russian regions. Management consultant, 2 (72-79).

Velikanov N.S. (2011). The socio-economic efficiency of consulting services. (Unpublished master's thesis). Moscow State University named after M.V. Lomonosov, Moscow.

Voskolovich H.A. (2007). The economy of paid services. Moscow: UNITY-DANA.

Zilberman M. (2006). Consulting: methods and technologies. SPb.: St-Pete.

Zvoronov A.F. (2002) The Market of audit and consulting services in Russia. Moscow: Maks-Press. 